PIOTR BLAJER OFM

Studium Biblicum Franciscanum

mieszkopb@gmail.com

\title{
Ewangelia Łukasza - świadectwo prawdziwości otrzymanego pouczenia
}

Łukasz jako jedyny spośród ewangelistów opatrzył swoje dzieło krótkim wstępem skierowanym do dostojnego Teofila (por. Łk 1, 1-4; Dz 1, 1-2). Wielu autorów uważa jednak, że chodzi o fikcyjnego adresata, a pod imieniem Teofil kryje się każdy, kto miłuje Boga $(\theta \varepsilon o ́ \varsigma ~ \varphi \iota \lambda \varepsilon ́ \omega)$. W świetle dotychczasowych badań nad ewangelią Łukasza trudno jednoznacznie określić, czy chodziło o konkretną osobę, czy też o fikcyjnego adresata. Niemniej jednak nie ma powodów, by wątpić, że chodziło o konkretną osobę, której prawdziwa tożsamość pomimo wielu prób identyfikacji, pozostaje nadal tajemnicą. Łukasz używa terminu „dostojny” w odniesieniu do rzymskich namiestników Feliksa (por. Dz 23, 26; 24, 2) i Festusa (por. Dz 26, 25). Teofil mógł więc być osobą, która zajmowała wysoki urząd w administracji rzymskiej. Stwierdzenie, czy chodziło o wierzącego, czy też nie, jest już bardziej skomplikowane. Kluczowym w tej sprawie jest

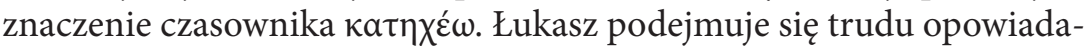
nia o wydarzeniach, jakie miały miejsce, aby Teofil mógł się przekonać o prawdziwości otrzymanego pouczenia, innymi słowy o prawdziwości otrzymanej katechezy. Jeśli zajrzymy do słowników języka greckie-

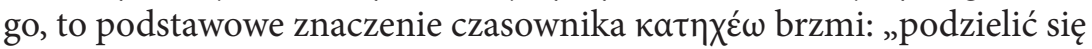


informacją, którą ktoś otrzymał" . Termin ten odnosi się zarówno do formacji chrześcijańskiej (Dz 18, 25; Gal 6, 6), jak i do każdej innej informacji. Co więcej, czasownik ten odnosi się także do negatywnego raportu (Dz 21, 21 - Paweł przybywa do Jerozolimy. Odwiedza Jakuba i starszych, którzy mówią mu, że miejscowi żydzi słyszeli [zostali poinformowani], że Paweł nawołuje do odstąpienia od Prawa Mojżeszowego). Być może Łukasz ma na myśli obydwa znaczenia tego czasownika. Teofil mógł być chrześcijaninem i jako taki otrzymał pouczenie dotyczące Jezusa, a jako osoba zajmująca wysoki urząd w administracji rzymskiej mógł też otrzymać donosy bądź też niezbyt przychylne informacje dotyczące chrześcijan. Najprawdopodobniej Łukasz należy do drugiego, a może nawet i trzeciego pokolenia chrześcijan, żyje więc w czasach, gdy rozpoczynają się prześladowania chrześcijan. Treść prologu wskazuje więc, że ewangelista Łukasz ma świadomość, iż nie jest ani pierwszym, ani jedynym, który podejmuje się przekazania świadectwa o Jezusie. Adresując swe dzieło do rzeczywistego bądź też fikcyjnego Teofila, Łukasz przyznaje, że $\pi 0 \lambda \lambda$ ò ع̇ $\pi \varepsilon \chi \varepsilon i ́ p \eta \sigma \alpha v$, co można przetłumaczyć dosłownie: „wielu przyłożyło rękę do opowiadania o wydarzeniach, które miały miejsce pośród nas" (por. Łk 1,1$)^{2}$.

Wprawdzie nie jest możliwe określenie $\mathrm{z}$ absolutną pewnością, kogo bądź też jakie wcześniejsze źródła Łukasz miał na myśli, gdy wspomina o „wielu”, niemniej można bezpiecznie założyć, że „wielu” odnosi się do więcej niż jednego autora czy też dzieła. Klasyczna teoria dwóch dokumentów bądź też dwóch źródeł mówi nam, iż Łukasz posłużył się ewangelią Marka, przynajmniej jeśli chodzi o część opisową ewangelii oraz źródłem Q. Łukaszowe bogactwo przypowieści, perykop poświęconych niewiastom, które podążały za Jezusem i posługiwały mu, jak i bogactwo informacji o Maryi wymaga także założenia, że Łukasz miał dostęp do dodatkowego źródła bądź też źródeł (Sondergut des Lukas). Źródła, którymi dysponował

${ }^{1} K \alpha \tau \eta \chi \varepsilon ́ \omega$, [w:] W. Bauer, W. F. Arndt, W. Gingrich, F. W. Danker, A Greek-English Lexicon of the New Testament and Other Early Christian Literature, Chicago-London $1979^{2}$.

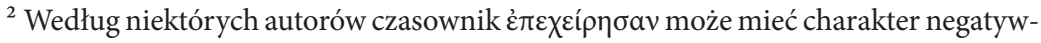
ny. Jeśli tak jest rzeczywiście, to w opinii Łukasza praca wykonana przez wielu autorów nie jest wystarczająca - por. G. Rossé, Il Vangelo di Luca, Roma 2001, s. 23-24. 
trzeci ewangelista, umożliwiły mu przedstawienie pełnego obrazu Jezusa, jego działalności, ale także pozwoliły mu na opowiedzenie, w jaki sposób naśladowcy Chrystusa kontynuowali misję rozpoczętą przez Mistrza.

\section{Analiza Łukaszowego prologu}

Na pierwszy rzut oka może się wydawać, że sam prolog, jak i sposób, w jaki Łukasz rozpoczyna ewangelię sugerują, iż kwestionuje on dotychczasową naukę, tradycyjny przekaz czy też dokładność przekazu o Jezusie ${ }^{3}$. Wydaje się bowiem, że gdyby istniejące wówczas przekazy były dokładne, Łukasz nie podejmowałby przecież trudu badań i opowiadania wszystkiego od nowa. Po prostu nie byłoby takiej potrzeby. Skoro jednak ewangelista podejmuje się tego zadania, to wydaje się, że w jego opinii czegoś jednak brakuje w istniejących wówczas przekazach, bądź też przekazy te nie są autentyczne lub prawdziwe. Rodzi się więc pytanie, czego brakuje $\mathrm{w}$ dotychczasowym przekazie, w jakim stopniu nie są kompletne.

Łukasz wspomina wielu, którzy podjęli trud przedstawienia wy-

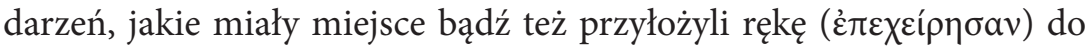
przedstawienia wydarzeń. Nie wymienia ich jednak z imienia tak jak było to w zwyczaju (i pewnie do dziś zostało w naszych akademickich status queastionis), by wskazać niedociągnięcia dotychczasowych dzieł i tym samym usprawiedliwić potrzebę napisania kolejnego. Łukasz nie wymienia kim są „liczni” ani też nie wskazuje na ich braki. Co więcej, on sam posiłkuje się istniejącymi ówcześnie źródłami (mam tu na myśli ewangelię Marka i źródło Q). Skoro tak jest, to myślę, że można śmiało stwierdzić, że w tym przypadku nie chodzi tyle o krytykę i uzupełnienie poprzednich dzieł, lecz raczej o dokładne przedstawienie wydarzeń i przekazanie ich w taki sposób, by odpowiadały potrzebom wspólnoty, do której Łukasz adresuje swe dzieło ${ }^{4}$.

${ }^{3}$ I. I. Du Plessis, Once More: The Purpose of Luke’s Prologue (Lk I 1-4), „Novum Testamentum" 16 (1974), s. 259-271.

${ }^{4}$ W sposób dobitny ujmuje to konst. Dei Verbum Soboru Watykańskiego II: „Święci zaś autorowie napisali cztery Ewangelie, wybierając niektóre z wielu wiadomości przekazanych 
W prologu Łukasz zobowiązuje się do dokładnego badania

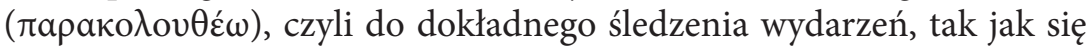

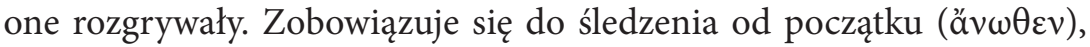
do badania wszystkiego ( $\pi \tilde{a} \sigma \iota v)$ i do poszukiwania dokładnego bądź też skrupulatnego (ảkpı $\beta \tilde{\omega} \varsigma)$. Całość pracy zamierza przedstawić po kolei i w sposób uporządkowany $(\kappa a \theta \varepsilon \xi \tilde{\eta} \varsigma)$.

Realizując tak założony plan, Łukasz, podobnie jak to czyni także Mateusz, rozpoczyna ewangelię od dzieciństwa Jezusa. Warto jednak zwrócić uwagę, że Łukasz nie tylko interesuje się początkiem życia Jezusa, ale także chce opowiedzieć o wszystkim ( $\pi \tilde{a} \sigma \iota v)$, co dotyczy Jezusa. W takiej perspektywie nie dziwi więc umieszczenie krótkiej informacji streszczającej dwadzieścia lat życia Jezusa: „wzrastał w mądrości, w latach i w łasce u Boga i u ludzi” $(2,52)$, jak również konieczność zebrania tradycji dotyczących życia pierwszej wspólnoty wierzących i napisania Dziejów Apostolskich. W ten oto sposób pierwszy tom dzieła Łukasza jest świadectwem Jezusa o Bogu, podczas gdy drugi tom jest świadectwem wiernych o zmartwychwstałym Jezusie, który objawia Boga i działa w Kościele poprzez swego Ducha. Dzieje Apostolskie podejmują i kontynuują tematy wprowadzone w ewangelii i zakładają jej znajomość oraz faktów, jakie ona opisuje. Łukaszowy prolog do Dziejów mówi bowiem: „w pierwszej $^{5}$ księdze napisałem o wszystkim, co Jezus czynił i czego nauczał od początku

ustnie lub pisemnie, ujmując pewne rzeczy syntetycznie lub objaśniając, przy uwzględnieniu sytuacji Kościołów, zachowując wreszcie formę przepowiadania, ale zawsze tak, aby nam przekazać szczerą prawdę o Jezusie. W tej przecież intencji pisali czerpiąc z własnej pamięci i własnych wspomnień, czy też korzystając ze świadectwa tych, którzy od początku byli naocznymi świadkami i sługami słowa, byśmy poznali prawdę tych nauk, które otrzymaliśmy" (19).

${ }^{5}$ Niektórzy autorzy (Spitta, Zahn, Ramsey i Knox) postulują, że Łukasz zamierzał napisać także trzecią część swego dzieła. Teoria ta opiera się na znaczeniu słowa $\pi \rho \tilde{\omega} \tau o \varsigma$, które w grece klasycznej sugeruje pierwsze spośród przynajmniej trzech. Greka helleni-

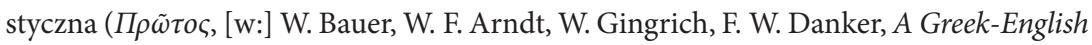
Lexicon of the New Testament, dz. cyt.) zna jednak przykłady, gdzie $\pi \rho \tilde{\omega} \tau o \varsigma$ oznacza pierwszy z dwóch. Nie ma więc potrzeby postulować istnienia trzeciej części dzieła Łukasza, które opowiadałaby o męczeństwie Pawła w Rzymie. 
aż do dnia, w którym pod wpływem Ducha Świętego udzielił pouczeń wybranym przez siebie apostołom i został wzięty do nieba" (Dz 1, 1-2).

Łukasz pisze, że podejmuje trud dokładnego badania, a więc podejmuje się spisania wydarzeń bez jakichkolwiek uprzedzeń i biorąc pod uwagę wszystko. Nie oznacza to jednak, że odrzuca on dotychczasową naukę ani tym bardziej tradycyjny przekaz o Jezusie. Wręcz przeciwnie, Łukasz w prologu zaznacza, że opiera swe dzieło na tradycji przekazanej

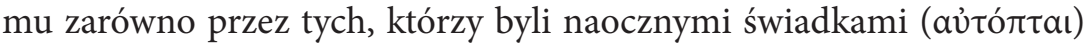

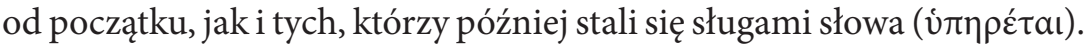
Warto w tym miejscu zaznaczyć, że w chwili wyboru Macieja, by zajął miejsce Judasza, Łukasz precyzuje kogo ma na myśli, mówiąc o naocznych świadkach i sługach słowa. Są nimi ci, „którzy towarzyszyli (Apostołom) przez cały czas, gdy Pan Jezus przebywał z (nimi), począwszy od chrztu Janowego aż do dnia, gdy został zabrany do nieba" (Dz 1, 21-22).

Łukasz opiera swe dzieło o autentyczną tradycję apostolską, która leży u podstaw życia ówczesnej wspólnoty chrześcijańskiej. Wielu było tych, którzy podejmowali próby spisania wydarzeń, jakie miały miejsce, niemniej jednak nauka zebrana przez Łukasza opiera się na świadectwie przekazanym przez dokładnie określoną grupę. Od samego początku Łukasz zaświadcza, iż pierwszym kryterium prawdziwości otrzymanego pouczenia jest tradycja apostolska przekazywana jak nauka z pokolenia na pokolenie lub z nauczyciela na ucznia. Bardzo dobrze wyraża to użyty w prologu czasownik $\pi \alpha \rho \alpha \delta i ́ \delta \omega \mu$, który między innymi oznacza przekazanie drugiemu tego, co się zna z tradycji ustnej lub spisanej i co osobiście ma duże znaczenie. Intencją Łukasza nie jest więc uzupełnianie istniejących opisów życia i działalności Jezusa i dodawanie do nich kolejnych wydarzeń lecz raczej zebranie tych tradycji i stworzenie dzieła jak najbardziej pełnego, mającego swą podstawę w tradycji apostolskiej.

Łukasz pragnie pisać o wydarzeniach, jakie się dokonały wśród nas. W tekście greckim mamy tutaj imiesłów czasownika złożonego $\pi \lambda \eta \rho \circ \varphi \circ \rho \varepsilon ́ \omega$ („spełniać, doprowadzić do końca”). Wybór tego czasownika wskazuje, że wydarzenia, o których mowa, są rzeczywistością dokonaną. Życie Jezusa ma swe dopełnienie w śmierci i zmartwychwstaniu, które z kolei pozwala zrozumieć wydarzenia i naukę Jezusa w czasie jego publicznej 
działalności. Innymi słowy w świetle wydarzeń paschalnych i mocą Ducha można spojrzeć na nowo na Jezusa i jego naukę.

Nie można w końcu zapomnieć, że Łukasz, podejmując się sporządzenia dzieła pragnie przedstawić wydarzenia po kolei i w sposób uporządkowany ( $\kappa \theta \boxminus \varepsilon \xi \tilde{\eta} \varsigma)$. Nie chodzi tu jednak tylko i wyłącznie o porządek chronologiczny lub geograficzny (ten również jest w pewnym stopniu zachowany, o czym za chwilę). Chodzi bardziej o koherentne i logiczne przedstawienie wydarzeń, jakie miały miejsce. Chodzi o przedstawienie tych wydarzeń w taki sposób, by ukazały działanie Boga w życiu i nauczaniu Jezusa.

Słownictwo użyte przez Łukasza w prologu wskazuje, że autor podchodzi do zadania z pełną świadomością ciążącego na nim obowiązku przekazania prawdy o Jezusie, by adresat lub adresaci upewnili się o prawdziwości otrzymanego pouczenia. Dzieło Łukasza ma zapewnić adresatów o stabilności i prawdziwości otrzymanego pouczenia. Tekst grecki używa tutaj rzeczownika ả $\sigma \varphi a ́ \lambda \varepsilon ı$. Rzeczownik ten wywodzi się od czasownika $\sigma \varphi \alpha ́ \lambda \lambda \omega$, który oznacza „wieść do upadku”. Rzeczownik à $\sigma \varphi a ́ \lambda \varepsilon ı$ z alpha privativa oznacza zapewnienie przed upadkiem, stąd możemy ten rzeczownik przetłumaczyć jako „pewność, prawdę, stabilne i bezpieczne okoliczności, bezpieczeństwo”. Dzieło Łukasza ma więc być dokumentem zabezpieczającym adresatów przed upadkiem.

Przekazując prawdę o Jezusie, Łukasz kieruje się dwoma zasadami: wierności źródłom i wolności w ich przedstawieniu. Łukasz jest wierny ewangelii Marka, ale gdy okoliczności na to pozwalają i wymagają, preferuje własne źródła, a niekiedy opuszcza całe sekcje ewangelii Marka (Mk 6, 45-8, 26; 9, 41-10, 12). Widać to dobitnie w scenach powołania pierwszych uczniów, początku działalności publicznej i wizycie w synagodze w Nazarecie. Opuszcza także bądź edytuje niektóre fragmenty, które mogłyby okazać się niezrozumiała dla czytelnika (wizyta krewnych Jezusa, śmierć Jana Chrzciciela, roszczenia synów Zebedeusza, epizod z drzewem figowym itd. $)^{6}$. Trudno odpowiedzieć jednoznacznie, dlaczego brak tych fragmentów u Łukasza, podczas gdy znajdują się u Mateusza.

${ }^{6}$ Por. Mk 3, 20; 6, 17-29; 10, 35-40; 11, 12-14. 20-21. 
Reasumując, analiza Łukaszowego prologu wskazuje, że przedmiotem dzieła są wydarzenia, które mają swoich naocznych świadków i jako takie są przedmiotem historiografii. Nic więc dziwnego, że Łukasz, redagując swe dzieło, postępuje według kanonów historiografii i używa słownictwa i zwrotów typowych dla tego rodzaju dzieła (podkreśla znaczenie wydarzeń, jakie miały miejsce, podejmuje dokładne badania i przedstawia je w sposób uporządkowany). Postępując w ten sposób, upodabnia swe dzieło do autorów hellenistycznych. Z drugiej jednak strony należy pamiętać, że w Łukaszowym dziele nie brak także elementów odwołujących się do literatury starotestamentalnej (powiedzeń mądrościach, przepowiedni proroczych itd). Co więcej, ewangelista jest świadomy, że przekazywanie wydarzeń, tradycji nie obyło się bez asystencji Ducha Świętego, mocą którego Jezus działa w swym Kościele. Cała działalność misyjna apostołów i ich pierwszych współpracowników odbywa się pod nieustannym wpływem Ducha Świętego. Widać to bardzo dobrze w niektórych fragmentach Dziejów Apostolskich. Pod wpływem Ducha Filip poucza etiopskiego eunucha. Duch porywa Filipa, którego widzimy głoszącego ewangelię w Azocie, a następnie docierającego do Cezarei (por. Dz 8, 29. 40). Działanie Ducha sprawia, że setnik Korneliusz i jego rodzina zostają przyjęci przez Piotra do wspólnoty wierzących w Jezusa (por. Dz 10, 11-16. 20. 44-47; 11, 12. 16). Duch interweniuje w społeczności w Antiochii i wybiera Pawła i Barnabę, by powierzono im misję (por. Dz 13, 2. 4). Duch Święty jest także protagonistą decyzji podjętych w czasie soboru jerozolimskiego, które dotyczyły przepisów prawa, do przestrzegania których są zobowiązani poganie przyjmujący wiarę w Jezusa (Dz 15, 28: „Duch Święty i my postanowiliśmy”). Pod wpływem działania Ducha Paweł udaje się do Frygii i Galacji, a następnie do Myzji (por. 16, 6-7) ${ }^{7}$. Ewangelia nie jest więc tylko i wyłącznie suchym $\delta ı n ́ \gamma \eta \sigma \iota \varsigma$, czyli uporządkowanym opisem faktów i wydarzeń, ale także świadectwem wiary, jest Dobrą Nowiną.

${ }^{7}$ Spośród licznych monografii dotyczących teologii trzeciego ewangelisty i pneumatologii warto zwrócić uwagę na dwie pozycje: G. C. Bottini, Introduzione all'aopera lucana, Jerusalem 2011, s. 149-152; F. Bovon, Luke the Theologian, Waco 2006, s. 225-272. 


\section{Plan narracyjny ewangelisty}

Łukasz jako jedyny spośród ewangelistów opatrzył swoje dzieło prologiem, w którym przestawia sposób, w jaki zamierza pracowaći cel swego dzieła. Po krótkiej analizie tego prologu warto zatrzymać się choć na chwilę i przyjrzeć, w jaki sposób Łukasz realizuje swój mistrzowsko założony plan, w jaki sposób przedstawia wydarzenia, jakie miały miejsce i w jaki sposób łączy je z Bożym planem zbawienia objawionym w tradycji Starego Testamentu.

Analiza planu narracyjnego ewangelii Łukasza, a więc analiza zmian miejsca, scen i głównych bohaterów, pozwala podzielić ewangelię Łukasza na sześć głównych części. Każda z tych części przyczynia się do poznania prawdziwego oblicza Jezusa, zapewnia poznanie całościowej prawdy o Jezusie (I ewangelia dzieciństwa 1, 5-2, 52; II działalność Jana Chrzciciela 3, 1-4, 13; III działalność Jezusa w Galilei 4, 14-9, 50; IV podróż do Jerozolimy 9, 51-19, 46; V działalność w Jerozolimie 19, 47-21, 38; VI męka, śmierć i zmartwychwstanie 22, 1-24, 53) ${ }^{8}$.

Uważna lektura ewangelii dzieciństwa stawia przed nami intrygujące pytania: Kim są rzeczywiści adresaci ewangelii? Do kogo Łukasz adresuję swe dzieło? Z prologu wiemy, że ma nim być dostojny Teofil, czyli najprawdopodobniej chrześcijanin wywodzący się spośród pogan, który zajmuje wysokie stanowisko $\mathrm{w}$ administracji rzymskiej. Jeśli więc adresatem ewangelii są osoby nie znające judaizmu, jak więc pogodzić z tym fakt, że ewangelia dzieciństwa wydaje się być dziełem skierowanym do żydów oczekujących Mesjasza, który przywróci Izraelowi należne mu miejsce. Zwiastowanie narodzin Jana Chrzciciela odbywa się w centrum kultu Izraela,

${ }^{8}$ Brak jednoznacznego konsensusu, jeśli chodzi o podział ewangelii. Bibliści proponują różne podziały. Na przykład C. H. Giblin, The Destruction of Jerusalem according to Luke’s Gospel, Rome 1985, s. 1-9 (Analecta Biblica, 107) proponuje podział na trzy główne części. B. Prete, L’opera di Luca, Torino 1986, s. 34-79 preferuje sześć części. J. A. Fitzmyer, The Gospel according to Luke, New York 1981, t. 1, s. 136-142 (Anchor Bible, 28) dzieli Ewangelię Łukasza na siedem części. Choć istnieje wiele propozycji podziału ewangelii Łukasza, to jednak wszyscy autorzy zgadzają się co do jednego: publiczna działalność Jezusa miała trzy części: Galilea, podróż do Jerozolimy, działalność w Jerozolimie. 
czyli w świątyni jerozolimskiej, co więcej, odbywa się to w chwili składania ofiary (por. 1, 5-25). Anioł Gabriel zostaje posłany do dziewicy. Objawia jej, że pocznie i porodzi syna, któremu nada imię Jezus. Będzie On zwany synem Najwyższego i Bóg da Mu tron jego ojca Dawida i będzie królował nad domem Jakuba na wieki. Innymi słowy zwiastowanie jawi się jako realizacja obietnicy złożonej Dawidowi przez proroka Natana (por. 2 Sam 7, 12-16). Co więcej, w Magnificat Maryja wielbi Boga za realizację obietnic danych Abrahamowi (por. 1, 55). Tych kilka przykładów wskazuje, że Łukasz nie tylko nawiązuje do starotestamentalnych tematów i przedstawia Jezusa jako królewskiego potomka Dawida, zbawcę i odkupiciela Izraela, ale także naśladuje styl pisania autorów Starego Testamentu' ${ }^{9}$. Początek ewangelii jest więc początkiem końcowego i chwalebnego rozdziału w historii Izraela.

Stylem przypominającym księgi prorockie („w piętnastym roku panowania cesarza Tyberiusza [...] Bóg przemówił do Jana na pustyni” - 3, 1-2) Łukasz dokładnie datuje początek misji Jana Chrzciciela. Historyczne odnośniki do osób i faktów mają zapewnić adresatów ewangelii o historyczności opisywanych wydarzeń, a jednocześnie umiejscowić opisywane wydarzenia w prorockiej tradycji Starego Testamentu (por. Iz 1, 1; Jr 1, 1-3; Ba 1, 1-2). Opis działalności Jana Chrzciciela ma zapewnić adresatów, że Jezus jest większy niż Jan Chrzciciel. W Łukaszowym opisie chrztu Jezusa w Jordanie brak na przykład jakiejkolwiek wzmianki, że to Jan ochrzcił Jezusa. U Łukasza zstąpienie Ducha Świętego i uroczysta proklamacja słów: „Ty jesteś moim synem umiłowanym, Ciebie sobie upodobałem" są ściśle złączone i wynikają z osobistej modlitwy Jezusa po chrzcie. Kuszenie na pustyni potwierdza Boże synostwo Jezusa i potwierdza prawdę objawioną już w ewangeliach dzieciństwa. Jezus jest Synem Bożym namaszczonym Duchem Świętym.

Jezus, pełen Ducha Świętego, rozpoczyna swą publiczną działalność w Galilei i przychodzi do synagogi w Nazarecie, gdzie odczytuje fragment z Księgi Izajasza, który w pewnym sensie przedstawia program działalności Jezusa: przyszedł, by głosić dobrą nowinę ubogim, więźniom wolność, niewidomym przejrzenie, wybaczać grzechy i wzywać do nawrócenia, a następnie działa i naucza w okolicach Jeziora Galilejskiego.

\footnotetext{
${ }^{9}$ J. A. Fitzmyer, The Gospel according to Luke, dz. cyt., t. 1, s. 45-56.
} 
W odróżnieniu od Marka i Mateusza Łukasz koncentruje niemalże całą początkową działalność Jezusa w Galilei. Konsekwentnie opuszcza wszelkie informacje, które nie odpowiadają temu planowi (u Łukasza na przykład brak informacji o miejscu wyznania wiary przez Piotra; według Mateusza i Marka miało to miejsce w Cezarei Filipowej, podczas gdy według Łukasza odbyło się to w bliżej nieokreślonym miejscu podczas modlitwy Jezusa) ${ }^{10}$.

Gdy nadchodzi czas, gdy Jezus miał być zabrany z tego świata, Łukasz przedstawia Jezusa rozpoczynającego podróż do Jerozolimy. Jezus nieodwołalnie postanawia iść do Jerozolimy. Tekst grecki przedstawia to postanowienie, by pójść do Jerozolimy w sposób bardzo obrazowy. W tekście

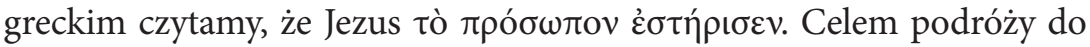
Jerozolimy jest åvá $\lambda \mu \psi$ ıc. Wśród filologów i egzegetów nie ma absolutnej zgodności co do znaczenia tego terminu; chodzi o śmierć czy raczej wniebowstąpienie $^{11}$. Przyjmując, że mowa tutaj o dniach, jak również, że w chwili przemienienia na górze Jezus rozmawiał z Mojżeszem i Eliaszem

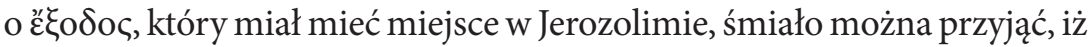
ảvá $\eta \mu \psi \iota \varsigma$ oznacza tutaj całą serię wydarzeń jak męka, śmierć i zmartwychwstanie, które prowadzą do wniebowstąpienia, a nie tylko o samo wniebowstąpienie, jak to proponuje bądź też proponowała większość komentarzy.

Cechą najbardziej charakterystyczną ewangelii Łukasza jest podróż Jezusa do Jerozolimy. Łukasz poświęcił tej podróży niemalże dziesięć rozdziałów, podczas gdy Marek zaledwie jeden rozdział (por. Mk 10), a Mateusz nie więcej niż dwa rozdziały (por. Mt 19-20). Łukasz przedstawia Jezusa zmierzającego do Jerozolimy, który jest przede wszystkim świadom swej misji, o czym świadczą trzy zapowiedzi męki (por. 9, 22; 13, 31-35; 18, 31-34), jak również jest świadom swej wyjątkowej relacji z Bogiem. Jezus często się

${ }^{10}$ Por. Mt 16, 13; Mk 8, 27.

${ }^{11}$ Łk 9, 51 jest jedynym miejscem w Biblii, gdzie występuje rzeczownik ảvá $\lambda \mu \psi \iota \varsigma$. Poza Biblią występuje on w Psalmach Salomona 4, 18. Według A. Denaux, The Delineation of the Lukan Travel Narrative within the Overall Structure of the Gospel of Luke, [w:] The Synoptic Gospels. Source Criticism and the New Literary Criticism, Leuven 1993, s. 373 (Bibliotheca

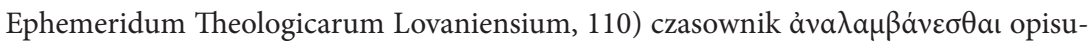
je wniebowzięcie Henocha (Syr 49, 14) i Eliasza (4 Krl 2, 9-11; 1 Mch 2, 58; Syr 48, 9). 
modli na osobności, a uczniowie, widząc to, proszą, by ich nauczył modlitwy. Jezus raduje się w Duchu i dziękuje Bogu, że ukrył przed mądrymi i roztropnymi, a objawił tym, którzy są jak małe dzieci (por. 10, 21-22). Po drugie, Jezus głosi królestwo i rozumie swą wyjątkową rolę w Bożym planie zbawienia. W sposób dobitny podkreślają to dwa fragmenty ewangelii: „szczęśliwe oczy, które widzą to, co wy widzicie. Bo mówię wam, że wielu proroków i królów chciało zobaczyć to, co wy widzicie, a nie zobaczyli, i usłyszeć to, co wy słyszycie, a nie usłyszeli” (10, 23); drugi fragment dotyczy znaku Jonasza (11, 29-32). Po trzecie, Łukasz przedstawia Jezusa jako współczującego i litującego się Mesjasza, który wzywa grzeszników do nawrócenia i niesie zbawienie tym wszystkim, którzy są w potrzebie. Nie sposób wymienić wszystkich fragmentów ewangelii Łukasza, które mówią o relacjach Jezusa z grzesznikami lub odtrąconymi, niemniej jednak najbardziej znanymi przykładami są przypowieści o miłosiernym Samarytaninie (por. 10, 25-37), synu marnotrawnym lub miłosiernym ojcu (por. 15, 11-32), faryzeuszu i celniku na modlitwie (por. 18, 9-14), czy też liczne przykłady uzdrowień, jak na przykład uzdrowienie dziesięciu trędowatych (por. 17, 11-19) lub niewidomego pod Jerychem (por. 18, 35-43) czy też wizyta w domu Zacheusza w Jerychu (por. 19, 1-10).

W ewangelii Łukasza podróż Jezusa do Jerozolimy kończy się lamentem nad miastem i zapowiedzią jej zniszczenia. Jezus, wchodząc do miasta, jest świadomy, że nie zostanie przyjęty w Jerozolimie jako Mesjasz. Niemniej jednak Jezus codziennie uczy w świątyni, co spotyka się z krytyką uczonych w Piśmie i starszych, którzy ostatecznie wydają Jezusa Piłatowi.

Łukasz przedstawia śmierć Jezusa na krzyżu w taki sposób, że pozwala nawet współwięźniowi wyznać niewinność Jezusa $(23,41)$, rzymskiemu setnikowi wyznać, że Jezus był naprawdę sprawiedliwy $(23,47)$, podczas gdy tłum wraca do domów, bijąc się w pierś $(23,48)$.

Wydarzania mające miejsce po śmierci i pogrzebie Jezusa stanowią finał planu narracyjnego podjętego przez Łukasza. Przy pustym grobie Jezusa aniołowie przypominają bowiem kobietom słowa Jezusa, że Syn Człowieczy musiał być wydany w ręce grzeszników, ukrzyżowany, by trzeciego dnia zmartwychwstać (por. 24, 7). W podobny sposób zmartwychwstały Chrystus tłumaczy uczniom na drodze do Emaus, że Chrystus musiał to wszystko wycierpieć, aby wejść do swej chwały (por. 24, 25). 
Innymi słowy zmartwychwstały Chrystus zapewnia, że wszystko dokonało się według tego, co przepowiedział Mojżesz i prorocy. Wydarzenia, jakie miały miejsce, nie są wynikiem jakiegoś przypadku czy fatum, ale są realizacją Bożego planu.

Łukasz kończy ewangelię opisem wniebowstąpienia Jezusa i powrotem uczniów do Jerozolimy. Ewangelia rozpoczyna się więc w świątyni jerozolimskiej (por. 1, 8-9) zwiastowaniem narodzin Jana Chrzciciela i kończy się w świątyni jerozolimskiej (por. 24, 53), gdzie uczniowie stale przebywają po wniebowstąpieniu Jezusa, wielbiąc Boga. Jerozolima i świątynia jerozolimska nie są jednak końcem misji Jezusa i jego uczniów. W Jerozolimie uczniowie oczekują bowiem napełnienia mocą z wysoka. Napełnienie mocą z wysoka i rozpoczęcie misji apostołów następuje w dniu pięćdziesiątnicy. Na poziomie narracyjnym Łukasz zaznacza to, używając tej samej konstrukcji gramatycznej i takich samych sformułowań, jakich użył w przypadku rozpoczęcia podroży Jezusa do Jerozolimy. Tak jak w chwili rozpoczęcia Jezusowej podróży do Jerozolimy pisał: ćv

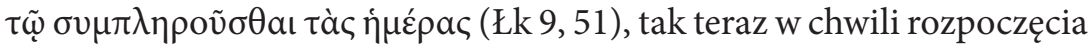

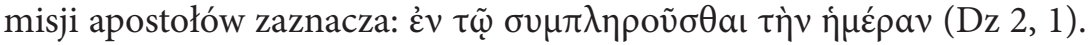
Są to jedyne dwa miejsca w Ewangelii i Dziejach, gdzie taka konstrukcja występuje. Ktoś może powiedzieć, że chodzi o przypadek. Być może, ale należy pamiętać, że Łukasz często odwołuje się do parzystego bądź też równoległego przedstawienia wydarzeń. Wystarczy spojrzeć na sposób, w jaki Łukasz przedstawia narodziny Jana i Jezusa. U Łukasza mamy też przypowieść o kobiecie szukającej drachmy i mężczyźnie szukającym owieczki (por. Łk 15), następnie mamy także przykład prośby modlitwy kobiety i przykład modlitwy faryzeusza i celnika (por. Łk 18) ${ }^{12}$. Na poziomie narracyjnym Łukasz upodobnia podróż Jezusa do Jerozolimy do misji apostołów. Tak jak misja Jezusa skierowana była z Galilei przez Samarię do Jerozolimy, tak samo misja apostołów ma być skierowana w przeciwnym kierunku: „będziecie moimi świadkami w Jeruzalem, w całej Judei, w Samarii i aż po krańce ziemi” (Dz 1, 8). Misja apostołów

${ }^{12}$ Istnieje jeszcze wiele innych przykładów równoległego przedstawienia wydarzen - por. C. H. Talbert, Literary Patterns, Theological Themes and the Genre of LukeActs, Missoula 1974. 
przestawiona w Dziejach Apostolskich podkreśla uniwersalny charakter zbawienia. Jest ono adresowanie nie tylko do żydów, lecz również do wszystkich narodów. Jezus jest zbawicielem całej ludzkości, stąd też Łukaszowy rodowód Jezusa prowadzi aż od Adama, a nie - jak to było w przypadku Mateusza - tylko do Abrahama.

\section{Podsumowanie}

Łukasz podejmuje się zebrania tradycji dotyczących Jezusa i życia pierwszej wspólnoty wierzących w niego, by zapewnić nowe pokolenie wierzących o prawdziwości otrzymanego pouczenia lub jak to widzieliśmy, analizując Łukaszowy prolog, stara się zapewnić stabilny fundament zabezpieczający przed upadkiem. Łukasz podejmuje się trudu ponownego zebrania i dokładnego zbadania tradycji o Jezusie, mając na myśli Kościół swych czasów, który zastanawia się nad swoim miejscem i znaczeniem w historii zbawienia. Trzeci ewangelista żyje bowiem pod koniec okresu apostolskiego i widzi konieczność ugruntowania Kościoła na tradycji apostolskiej (por. prolog, gdzie daje głos naocznym świadkom i sługom słowa). To właśnie autentyczna tradycja apostolska przekazywana z pokolenia na pokolenie pod asystencją Ducha Świętego staje się podstawowym wymogiem prawdziwości głoszonej ewangelii. Łukaszowe dzieło opiera się na tradycji o Jezusie, jest realizacją zapowiedzi proroków i realizacją Bożego planu zbawienia. Przez to staje się prawdziwą i autentyczną wykładnią nauki o Jezusie, wykładnią prawdy o Jezusie, który działał w mocy Ducha, a także wykładnią prawdy o początkach Kościoła, w którym działał sam Jezus poprzez swego Ducha. Jednocześnie dzieło to staje się apologią przeciwko atakom skierowanym przez prądy synkretyczne czy też heretyckie. Celem dwóch tomów jest więc ustalenie i przekazanie żywej tradycji o Jezusie (Ewangelia), jak i żywej tradycji o życiu pierwszej wspólnoty wierzących w Jezusa (Dzieje Apostolskie) ${ }^{13}$.

${ }^{13}$ H. Schürmann, Il vangelo di Luca, Brescia 1983, t. 1, s. 95-96. 


\section{Abstrakt}

Ewangelia Łukasza jaka jedyna rozpoczyna się od prologu, w którym ewangelista wskazuje cel dzieła, którego się podejmuje. W prologu tym Łukasz przyznaje, iż nie jest pierwszym, który podejmuje się spisania wydarzeń związanych z życiem i działalnością Jezusa. Choć wielu wcześniej podjęło próbę opisania wydarzeń jakie miały miejsce to jednak Łukasz dostrzega potrzebę ich ponownego i dokładnie uporządkowanego przedstawienia. Celem tego artykułu jest przeanalizowanie Łukaszowego prologu i planu narracyjnego ewangelisty wskazanego w tymże prologu jak również wskazanie kryteriów autentyczności otrzymanego pouczenia. Autor rozpoczyna od językowej analizy prologu i użytych w nim słów. Następnie omawia plan narracyjny ewangelisty i podział ewangelii na poszczególne sekcje a w sposób szczególny na obszerną sekcję podróży Jezusa do Jerozolimy $(9,51-19,46)$. Na zakończenie autor wskazuje na paralelne przedstawienie początku podróży Jezusa do Jerozolimy i rozpoczęcia misji apostołów (Łk 9, 51, Dz 2, 1).

\section{Słowa kluczowe}

Ewangelia Łukasza, Łukaszowy prolog, podróż Jezusa do Jerozolimy, plan narracyjny Łukasza

\section{Abstract \\ The Gospel of Luke - witness to the certainty of the received teachings}

The Gospel of Luke is the only gospel that begins with a prologue. In this prologue Luke admits that he is aware that others have already attempted to write about events associated with the life and work of Jesus Christ. Although many have previously tried to describe the events that took place, Luke still feels need to recount them once again in a proper order and manner. The purpose of this article is to analyze Luke's prologue as well as the plan of the third gospel presented in the prologue. Furthermore, the article analyses the criteria for certainty of received teaching which are the bases for Luke's writings. The author begins with a linguistic analysis of the prologue. Then, he discusses the narrative plan of third evangelist and the gospel division into separate sections. He pays 
a special attention to so-called journey section which describes Jesus' journey to Jerusalem (9:51-19:46). In conclusion, the author points to parallel presentation of Jesus' journey to Jerusalem and the mission of the apostles (Luke 9:51, Acts 2:1).

\section{Keywords}

Gospel of Luke, Luke's prologue, Jesus' journey to Jerusalem, narrative plan of Luke

\section{References}

Bauer W., Arndt W. F., Gingrich W., Danker F. W., A Greek-English Lexicon of the New Testament and Other Early Christian Literature, Chicago-London $1979^{2}$.

Bottini G. C., Introduzione all'aopera lucana, Jerusalem 2011.

Bovon F., Luke the Theologian, Waco 2006.

Denaux A., The Delineation of the Lukan Travel Narrative within the Overall Structure of the Gospel of Luke, [w:] The Synoptic Gospels. Source Criticism and the New Literary Criticism, Leuven 1993 (Bibliotheca Ephemeridum Theologicarum Lovaniensium 110).

Fitzmyer J. A., The Gospel according to Luke, t. 1, New York 1981 (Anchor Bible, 28).

Giblin C. H., The Destruction of Jerusalem according to Luke's Gospel, Rome 1985 (Analecta Biblica, 107).

Plessis Du I. I., Once More: The Purpose of Luke's Prologue (Lk I 1-4), „Novum Testamentum" 16 (1974), s. 259-271.

Prete B., Lopera di Luca, Torino 1986.

Rossé G., Il Vangelo di Luca, Roma 2001.

Schürmann H., Il vangelo di Luca, Brescia 1983.

Talbert C. H., Literary Patterns, Theological Themes and the Genre of Luke-Acts, Missoula 1974. 
